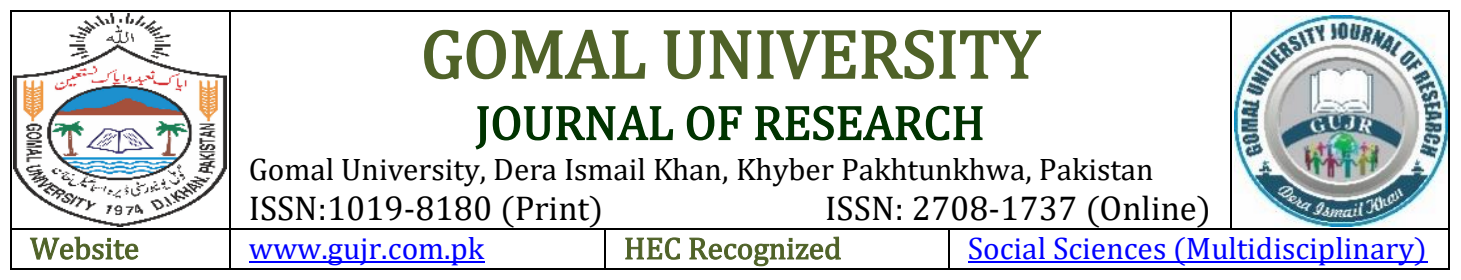

\title{
CO-EDUCATION VERSUS SINGLE-GENDER EDUCATION: INFLUENCE OF DIFFERENT EDUCATIONAL SYSTEM ON THE STUDENT SELF-ESTEEM, CONFIDENCE LEVEL, AND ACADEMIC ACHIEVEMENT IN PAKISTAN
}

\author{
Bushra Yasin ${ }^{1}$, Muhammad Azim ${ }^{2} \&$ Aminah Qayyum ${ }^{3}$
}

${ }^{1}$ Assistant Professor, Department of Education, University of Jhang, Jhang, Pakistan

${ }^{2}$ Department of Cybernetics, Faculty of Science, University in Hradec Králové, CZECHIA ${ }^{3}$ Department of Education, Government College for Women University, Faisalabad, Pakistan

\section{ARTICLE INFO \\ Keywords: \\ Co-Education, Single- \\ Gender Education, \\ Self-Esteem, \\ Confidence Level, \\ Academic Achievement}

Article History:

Date of Submission:

19-09-2020

Date of Acceptance:

18-12-2020

Date of Publication:

31-12-2020

\section{ABSTRACT}

Different education sectors are playing active role in the development of students like performance, self-esteem, and confidence. To fulfill the study purpose, the researcher used 2 scales (Rosen Berg self-esteem and Dr. John confidence level scale) and collected the data from the students of both of the specified educational settings. The students of universities of the district Faisalabad were the study population, and students of 3 selective universities were the sample of the study. After data collection, the researcher applied one-way ANOVA to check the impact of all variables on students' academic achievement. The study results showed no significant impact of both types of education on students' academic achievement but it has a significant impact on their confidence level and the self-esteem. At the end of the paper, it was recommended that teachers need to focus on student confidence level and self-esteem to build their good personalities leading to the higher academic achievements.

\begin{tabular}{|c|c|}
\hline & (c) (9) \& 2020 Gomal University Journal of Research \\
\hline Corresponding Author & Aminah Qayyum: amna.qayum92@gmail.com \\
\hline DOI & https://doi.org/10.51380/gujr-36-02-09 \\
\hline
\end{tabular}

\section{INTRODUCTION}

Single-sex education is the system of instruction where girls and boys are taught in the separate settings, buildings, classrooms or schools. The single-sex education was more common before the mid-twentieth century, especially in secondary education and high secondary education in developing countries like Pakistan and India (Khalil, Hashish \& Dawood, 2011). The discussion about the pros and cons of single-gender and co-education begins from the previous ten years. In the 1920s, it was articulated that co-education could help overcome gender bitterness, reduce homosexuality, and result in better marriage quality. In the 1960s, it was assured that students were more contented in co-educational settings. After that, in the middle of $20^{\text {th }}$ century feminist 
painted that single-gender schools were more suitable for female students while co-education was more suitable for male students. At the end of $20^{\text {th }}$ century, this discussion was raised with issue of which schooling results in better academic achievement. Some proofs signify that singlegender education could assist in getting better school results. Thus, the discussion extends as Yates (2004) said, from the last thirty years, the comparative qualities of single-gender and coeducation for learning and psychological growth of the school going students have been argued widely.

According to Datnow and Hubbard (2002), there are many advantages of single-sex education for the girls and boys because it provides the learning environment that prevents students from distracted. Some investigators defend that single sex schooling is more advantageous for male students because it enhances the male interaction and maximizes male qualities (Hawley, 2013; Reisman, 2017). Besides this, male students are more expected to practice their real concerns in single-sex school instead of following those conventional subjects for boys in the co-educational schools (Hudley, 1995; Riordan, 2014). The National Association for the Single-gender Public Education (NASSPE, 2005) highly prefers single-gender education. It indicates that "boys in allboys schools are more than twice as likely to the study subjects such as foreign languages, arts, music and drama. While girls study home economics and different teaching subjects," NASSPE further highlights its debate regarding the study conducted at Cambridge University, UK. The study discovered the results of single-gender settings in schools in the four different localities. Together with the rural, suburban and inner-city schools and study, the single-gender classes were an important issue in constituting the school values and maximizing the student learning achievement.

For example, at a co-education school in Leeds, only one-third of boys received passing marks in German and French. After entering single-gender classes, all boys achieve the passing marks (NASSPE, 2006). Other than this some more favorable circumstances of single sex schools were examined with assistance of various studies which stated more effective examples for students; utilizing of differential ability and different methods of learning for students; reducing gender gaps in the subjects like arithmetic and science; diminishing sex biases by educators among students' correspondence; diminishing sex generalizations and conditions for high number of authority opportunities to students (Lee \&Bryce, 1986; Riordan, 1994; Lee \& Lockheed, 1990; Harker, 2000; Dale, 1974). Today, self-esteem is one of the powerful factors which influence the student academic achievement has received the expanding consideration. The pupils who have higher academic achievement will feel more confident compared to the individuals who are not confident in them and accomplish less. The self-esteem can be referred to individual worldwide decisions of competency regarding one's self-esteem (Harter, 2018). This thing rises when kids contrast their self-assessment and actual performance in daily life activities on assortment of assignments.

It is a general concept; high confidence helps people see themselves as dynamic and proficient people to advance the changes through exertion and set more significant standards that cause learning new thing. Interestingly, various analysts have exhibited that ideal approach to expand student academic achievement is to expand their confidence (Rubie, Townsend \& Moore, 2020). Research has been conducted that high confidence assumes a significant function in academic achievement, social and the moral obligation (Redenbach, 2014). The individuals who have high academic achievement will feel more confident compared to those who are less confident or no 
confidence at all. The research studies combining all these variables in both gender education was missing in our context; hence this was a wide gap that the researcher tried to cover through this study. By observing this relationship among variables, this study was conducted to see the effect of these variables on the students studying in the single-sex education and the students studying in co-education sectors. Single-sex education means to educate the girls or boys in a separate school setting, while the co-education is the assimilation of both the sexes in the same educational setting. Through this study, the researcher intends to find the impact of single sex education and co-education on the student self-esteem, academic achievement, and confidence level.

It was observed that there is variation in boys and girls learning styles, self-esteem, confidence, and academic performance, which may affect them differently. Self-esteem is the area that has focused on girls and boys in different ways in which it affects their academic performance and their overall well-being and success in life. This paper attempted to investigate these issues, how self-esteem, confidence and achievement are affected educationally and emotionally indifferent educational settings., single-gender or co-education. These days, due to some budget restraints, most institutions and universities are investigating how to bring down their expenditures and provide quality education to the students. To provide better academic setup and tackle thinking and nature of urban and rural people, some districts established single-gender schooling. In the same districts, co-educational schools were established, but single-gender classes were arranged to tackle students' performance issues in that setup. The observed student performance was the same as in single-gender schools (Ogden, 2011). So, eradicating single-sex schools can help save building funding, skilled growing factors, transport resources and staff members for separate schools. Students of single-gender and co-education school have to compete efficiently in global world.

Hence, this study's basic reason is to determine the impact of the co-education and single gender education on the self-esteem, confidence, and academic achievement of students at university level in Faisalabad District of Pakistan. This study is significant in many contexts for students, teachers, and parents as well. Universities play a pivotal role in pupils shift from lower-level to higher-level education. By keeping in view, raised demand for qualified and competent teachers, higher education institutions should use practical actions to comply with this demand. As these institutions are trying to apply these practices, performance, self-esteem and confidence of the students in single-sex and co-educational schools is main focus of the research. The study results may be useful for various professionals by explaining how single-gender or co-education sectors affect students in various senses. It may be helpful for development of teachers to improve their teaching methods. It may help to decide about suitable allotment of teachers, administration and various resources. It may also help parents view difference between both types of education and its impact on students. Study may help govern how single-gender education and co-education may be advantageous for the boys' and girls' academic achievement, self-esteem, and confidence level.

\section{Research Objectives}

$>$ Investigate the impact of co-education and single-gender education on the self-esteem of students.

$>$ Find out the impact of co-education and single-gender education on the confidence level of students. 
Yasin et al... Co-Education Versus Single-Gender

$>$ Explore the impact of the co-education and single-gender education on the academic achievement of students.

\section{Research Questions}

1. Is there any impact of co-education and single-gender education on the self-esteem of students?

2. Is there any effect of co-education and single-gender education on the confidence level of students?

3. What is the impression of co-education and single-gender education on the academic achievement of students?

\section{LITERATURE REVIEW}

Several followers of the single-gender schooling rely on that it assists the learners to learn more efficiently. The experts of single gender education said that male and female students learn with different methods due to physical variations in brains of girls and boys. The studies conducted on the male and female brains point out that males and females practice evidence using various parts of their brains. This is proved through problem-solving capacities of males and females. For example, when someone asked for direction from males, they use the left hippocampus (a part of the brain) and mostly use theoretical ideas like east or west. Contrary to this, females use the cerebral cortex (a part of brain) and will denote direction with famous landmarks that can be accessed easily to find way. Fans of single-gender education believe that these differences exist in the understanding, communication, and perception of males and females. If something pleases a female, it may bore boy and vice versa (NASSPE, 2006). Opponents of single-gender education believe that without opposing gender, learners are poor of learning environment that is design of their real life. These results in minimum interaction and lack of the skill to deal with students of all genders in school settings, which enhances unawareness and injustice for other genders.

It is also necessary to indicate that co-education may also lead to better cognitive and emotional situations. Mael (1998), show true depiction of life can be observed in co-education classrooms, resulting in more socialization than the single-gender schooling. Co-education mitigates gander gaps. In another study, Salomone (2006) stated that students studying in single-gender schools are usually more confident and have different interests. In single-gender schools, teenage girls are especially interested in subjects like math and science, and they feel more relaxed and show an encouraging attitude towards these subjects. She also described that single-gender education encourages boys' interests in liberal arts subjects like languages because they feel it easy. Finally, it is evident that single-gender education never results in stereotyping; it enhances the learning period of girls and boys. Self-esteem is the artifact of one's opinion, self-respect and confidence. The main thing for self-esteem is difference between the wish of individual and what he attains and how assistance he takes from others in the process (Rosenberg, 1965). The students' selfesteem is how much extent student academic achievement matches academic expectations and requirements. More self-esteem level leads to positive effects and returns usually in the adult students.

Those students who have the high level of self-esteem remain cool towards every one, feel easy with everyone, do not use addictive things to make themselves relax, do tough jobs, be more social, feel pleasure, and are good in studies. Contrary to this, those students with a low level of 
self-esteem are usually anxious, not social, have a lack of confidence, addicts, remains depressed and usually poor academically (Wiggins, 1994). Motivation, self-esteem, confidence, freedom, control, and competencies are the factors that effect on the academic performance of everyone (Helat, 2007). From the start of the twentieth century, many research types were conducted to compare the single-gender and co-educational school settings (Lee \& Bryk, 1986; Lee \& Marks, 1990). The most numerous arguments were the effect of these both types of schooling on pupils' achievement in different subjects like, science, math, art, music, history, and others in fixed time duration (Murphy \& Ivinson, 2000). There are still many opinions about these two categories of schools. Still, there is commonly no agreement on which category of schooling is better for students concerning educational services it provided. A study was conducted by Malik (2011) with the view to observe the opinions of the students regarding single-gender education and coeducation.

The study results were that, among 150 students, half of the students showed positive opinions for the single-gender education system. In our country Pakistan, the single-gender schooling is observed in public institutions till secondary schooling. Conversely, in private institutions, both types of education are present in large numbers. Since there is shortage of data to compare the single gender and co-education schooling in Pakistan that is why there is massive need to search about the advantages and disadvantages of these both types of schooling in context of Pakistan's culture. The current study is an attempt to work from the same perspective. It aims to check either male students develop a more positive attitude than female students, with the view to compete with female students in co-education system. Similarly, its purpose is to check whether male or female students develop more positive attitudes to compete with same gender students while studying single-gender schooling. Besides the discussion for single-gender education, coeducation's main advantages are development of students with respect to different aspects like social development, moral, and personal development. Robinson and Smithers (1999) said that to educate both gender students in same educational setting is like real and practical life, and experiences gained make it convenient for students to go with a mixed setup of employment and university.

Numerous different studies helps co-education are that, in co-education framework less number of classes are required, working of school, number of instructors, more agreeable connection between both sex of students, better learning with reasonable adjustment for good family life and so on co-schooling energize information, concordance, observation, normal regard for other people, view of females function in public arena, regard for female freedom and their endeavors for sexual orientation reasonableness, figure out how to work helpfully and figure out how to act shrewdly in presence of inverse sex (Marsh, 1989 \& 1991; Goldstein, 1987). According to study "the research position on the effects of mono- and co-education is so far inconclusive". Some writers consider two types of co-education, first is full-time co-education, and the second one is separate classes of both genders for a short time. It was observed from the studies conducted in New Zealand and Flanders that there are no profits of single-gender education. In same sense, Ruessel (2007) said, exponents of single gender education said that people of both genders have diverse needs and learn very differently from each other. They represent data which showed that males and females are in dispute in a mixed-gender setting. Co-education exponents argue that mixed gender classes are more linked with moral codes and can adjust in the society (Ruessel, 2007). 
All these researches represent a reliable depiction concerning the pros and cons of both types of education. In Riordan (1994) detailed literature, discussion for and against single-gender and co-education schooling was reviewed. As Park, Behram and Choi (2013) investigated essential effects of single-gender schools on college admission and exams. They highlighted that singlegender schools produce more graduates than co-education. Nagengast, Marsh and Hau (2013) conducted a similar study in which they used matching analysis and experience little indication for positive effects of single-gender education on high school students' results. On other hand, Jackson (2012) stated that most pupils could not perform better in single-gender schooling. The same results were also found by Harker (2000). Then, it was observed the effect of single-gender education for a long time. They all investigated females' educational achievements that singlegender schooling is good for females until age 16 , but it is neutral for male students. It was also stated that males and females educate in more gender-based subjects or areas due to separate schooling in different jurisdictions. The effect of single-gender education has also been observed with the view of opportunities for specific study programs. For instance, Cherney and Campbell (2011) investigated that the students from the single-gender schools contribute more to physical sciences.

In many cultures, single-gender education is supported with reference to the customs and their religious traditions in various parts of the world. Many schools in the Middle East are providing single-gender education, but co-education in those areas is liked. Many universities in countries like Jordan, United Emirates, Iran, and Egypt are providing co-education. It was observed in 2002- 2006 that the ratio of female applicants in those universities was the sixty percent. Many countries like Pakistan and Saudi Arabia were strictly against the co-education system because it is against the rituals of Islam and Islam prohibits the mixing of man and woman. The schools and almost all educational institutes were single-gender only till the 2oth century. In the 21st century, about in 2009, the first co-education university was established with the King Abdullah University of Science and Technology. There were almost 80 professors and 850 students, and all were foreigners. In developing countries and especially in Islamic countries, the indications about co-education schools are minor. In Pakistan, co-education system was first started from province Sindh where only the primary schools were having co-educational setup, but now this trend is now spread and all provinces primary schools have co-education in all private and public schools.

The trend of co-education in secondary schools is also now increasing day by day. Most private schools off co-education at the secondary level, but in government schools, this trend is not yet observed. In federal areas, the co-educational schools set up are not supported that is why there are single gender schools for girls and boys. In addition, primary schools (junior model primary schools) are of both types, i.e., single-gender a co-education as well. These schools are very few in number and were started as a project in 1971. In the province of Punjab, it was seen that in single gender schools, boys and girls' study collectively under same roof. These conditions take place when parents prefer their children to study in opposite sex schools. The reasons to send their children in a co-educational setting are insufficient number of teachers, absence of basic facilities i.e., no drinking water, no boundary wall of the school, and absence of toilets, especially for female students. Besides this some other reasons like distance of school from home, younger siblings like to go with their elder brother or sister in school. Infect these cases are rare, and now education is free in all primary schools. The private separate sex schools are present in those 
areas, but most people prefer to send children to government co-education schools due to cost savings.

Overall, these conditions have missed females backward and males excel in every field of life. These gender prejudices are very common in all traditionalist areas or provinces of Pakistan. This concept has more prevailed in most traditional tribes of all Pakistan. This situation leads to a lower female literacy rate. So, the idea of the co-education is ignored in traditional societies of Pakistan (Ahmad, 1984). Due to the shortage of female schools and discrimination against females, females' literacy rate is very low in these areas (Zafar, 2004). This condition is worse in Pakistan tribal areas where co-education is depressed (Ministry of Education, 1989). Without understanding role of women in different fields, no society can excel from other societies. This gender discrimination is involved in inequality, social conflict and role crises, becoming cause of crimes. In Pakistan, women have unequal rights like socially remote and culturally confined. There are various cultural, religious and political hurdles to co-education in Pakistan (Pirzado, 2006). These gaps also exist in facilities provided to males and females in different situations of life (Lavigueur, 1980). As observed, in modern societies, females work equally with males, and society moves towards prosperity (Hashmi et al., 2008). Co-education is considered the demand of today world, but it is still not allowed in Pakistan backward areas (Department of Education, 2008).

\section{RESEARCH METHODOLOGY}

The methods and procedures used for conducting this study have been presented in this section in order to ensure necessary tools and techniques that are vital in chasing the research objectives systematically.

\section{Nature of Research}

The nature of the study was quantitative in nature and survey research design was used to fulfill the purpose of the study in order to access the population and to extract the desired information through their opinions about the issues under considerations in this research study to offer new knowledge.

\section{Population}

The study populational the students of co-education and single-gender universities of district Faisalabad wherein the sample has been drawn by following the standard procedure to present sample.

\section{Sample and Sampling Technique}

From 23 universities in Faisalabad, 3 universities were selected conveniently and then a sum of 180 students was taken as the sample of the study. The 3 universities were selected because each institution showed a clear representation of gender means 1 was an only male institution, 1 only female, and 1 was offering the co-education. The researcher take sample from three departments (20 from each department), 60 students university in which only female students are studying (government college university for women, Faisalabad), 60 from the university in which male students are studying (Government Postgraduate College for boys, Samanabad, Faisalabad) and 60 from co-education university (Government college for women university, Faisalabad) either universities belong to public or private sector. Convenient sample technique was used to collect data. 


\section{Tool of Research}

The data was collected using Rosenberg (1965) self-esteem and John (2001) self-confidence scales. The academic performance of the student was measured by comparing current academic marks with their all seven-semester marks. These instruments are validated by developers and consider being reliable to use in the different context and therefore recommended as valid and reliable.

\section{Data Analysis Technique}

The results were analyzed through SPSS by using one-way ANOVA, the parametric test, on all objectives to find the impact of co-education and single-sex education on students' self-esteem, the confidence level and the academic achievement as hypothesized through different research questions.

\section{RESULTS OF STUDY}

The data analyzed through different statistical procedures and tools have been presented in this section in order to find the answers of research questions and to reach the conclusion of study systematically.

\section{Table 1}

Socio-demographic and Personal Characteristics of the Study Sample

\begin{tabular}{llcc}
\hline Variable & Category & Frequency & Percentage \% \\
\hline Age & $17-22$ & 180 & 100 \\
Academic & $60-70 \%$ & 95 & 52 \\
achievement & $71-80 \%$ & 78 & 43 \\
& $81-90 \%$ & 6 & 4 \\
\multirow{3}{*}{ University Type } & $91-100 \%$ & 1 & 1 \\
& Single Gender Male & 60 & 33 \\
& Single Gender Female & 60 & 33 \\
& Co-Education (Male \& Female) & 60 & 34 \\
\hline
\end{tabular}

Table 1 shows the socio-demographic characteristics of the study sample. The whole sample was from same age group that ranged between (17-22) years. With respect to academic achievement, most of the study sample was very good; their achievement ranged between (60-70\%). The study sample was selected equally from all types of the education systems: the single-gender education system, either males or females, and co-education. Table 2 indicates descriptive statistics used for the sample. The mean value of the self-esteem level of females studying in the single-gender education is greater than males in single-gender education and co-education students. The mean value of males' confidence level studying in single-gender education is higher than others, and mean value of students studying in co-education is higher than the single-gender education system.

Q1: Is there any impact of co-education and single-gender education on the self-esteem of students?

The following table compares impact of co-education and single-gender education on students' self-esteem. 
Yasin et al... Co-Education Versus Single-Gender

Table 2

Descriptive of Study Sample

\begin{tabular}{llcccccccc}
\hline & & $\mathrm{N}$ & Mean & SD & SE & \multicolumn{2}{c}{ 95\% CIM } & Minimum & Maximum \\
\hline \multirow{5}{*}{ Self-esteem } & SGM & 60 & 4.27 & .918 & .119 & 4.03 & 4.50 & 3 & 7 \\
& SGF & 60 & 4.83 & .642 & .083 & 4.67 & 5.00 & 4 & 6 \\
& CMF & 60 & 4.58 & .696 & .090 & 4.40 & 4.76 & 3 & 6 \\
& Total & 180 & 4.56 & .792 & .059 & 4.44 & 4.68 & 3 & 7 \\
Confidence & SGM & 60 & 2.10 & .477 & .062 & 1.98 & 2.22 & 1 & 3 \\
& SGF & 60 & 1.88 & .524 & .068 & 1.75 & 2.02 & 1 & 3 \\
& CMF & 60 & 2.02 & .431 & .056 & 1.91 & 2.13 & 1 & 3 \\
& Total & 180 & 2.00 & .484 & .036 & 1.93 & 2.07 & 1 & 3 \\
& SGM & 60 & 2.12 & .715 & .092 & 1.93 & 2.30 & 1 & 3 \\
& SGF & 60 & 1.93 & .880 & .114 & 1.71 & 2.16 & 1 & 3 \\
& CMF & 60 & 2.17 & .827 & .107 & 1.95 & 2.38 & 1 & 3 \\
& Total & 180 & 2.07 & .812 & .061 & 1.95 & 2.19 & 1 & 3 \\
\hline
\end{tabular}

SGM: Single-Gender Male, SGF: Single-Gender Female, CMF: Co-Education (Male and Female)

Table 3

Summary of ANOVA for Students' Self-Esteem by Type of University

\begin{tabular}{|c|c|c|c|c|c|c|}
\hline Self-esteem & & Sum Squares & $\mathrm{df}$ & Mean Square & $\mathrm{F}$ & Sig. \\
\hline \multirow[t]{3}{*}{ Self-esteem } & Between Groups & 9.678 & 2 & 4.839 & 8.344 & $.000^{* *}$ \\
\hline & Within Groups & 102.650 & 177 & .580 & & \\
\hline & Total & 112.328 & 179 & & & \\
\hline
\end{tabular}

**P<0.01

The results of the above table $\mathrm{F}(2,4.8)=8.344, \mathrm{P}=$. .ooo shows the summary of the ANOVA table for the self-esteem level of students of different types of education. The table shows that a significant difference exists between self-esteem level of males and females studying in singlegender education and students studying in co-education system in the particular context under study.

Q2: Is there any influence of co-education and single-gender education on confidence level of students?

Table compares influence of co-education and single-gender education on students. confidence level.

Table 4

Summary of ANOVA for Confidence Level by Type of University

\begin{tabular}{llccccc}
\hline & Sum Squares & $\mathrm{df}$ & Mean Square & $\mathrm{F}$ & Sig. \\
\hline Confidence & Between Groups & 1.433 & 2 & .717 & 3.127 & $.046^{*}$ \\
& Within Groups & 40.567 & 177 & .229 & & \\
& Total & 42.000 & 179 & & & \\
\hline
\end{tabular}

${ }^{*} \mathrm{P}<0.01$ 
Results of above table $\mathrm{F}(2, .717)=3.127, \mathrm{P}=.046$ reflects the summary of the ANOVA table for the confidence level of students of different types of education. The table shows the valuable information that the significant difference exists among the confidence level of the males and females studying in the single gender education and the students studying in the co-education system.

Q3: What is impact of co-education and single gender education on academic achievement of students?

Table compare impact of impact of co-education and single gender education on student academic achievement.

\section{Table 5}

Summary of ANOVA for Students' Academic Achievement

\begin{tabular}{lccccc}
\hline & Sum Squares & $\mathrm{df}$ & Mean Square & $\mathrm{F}$ & Sig. \\
\hline Between Groups & 1.811 & 2 & .906 & 1.379 & $.255^{* *}$ \\
Within Groups & 116.250 & 177 & .657 & & \\
Total & 118.061 & 179 & & & \\
\hline$*$ P $>0.01$ & & & & &
\end{tabular}

Results of above table $\mathrm{F}(2, .906)=1.379, \mathrm{P}=.255$ indicates the summary of the ANOVA table for the academic achievement of students of different types of education. The table shows that there is no significant difference in opinion among the academic achievement of the males and females studying in the single gender education and the students studying in the co-education system.

\section{DISCUSSION \& CONCLUSION}

Finally, it is concluded from the results of the study that there is a significant difference in selfesteem and confidence level of students studying in the single-gender education system or either in co-education system. Because self-esteem and confidence level of students is affected by the type of environment in which they spend more time. On the other hand, no significant difference was observed in the academic achievement of students of both types of education. The academic achievement of students depends on their intelligence level and interest in studies, either they are boys or girls or either they study in co-education system or single-gender education system. So, this paper has allegations to focus on confidence development and to build up self-esteem level of students because these have a positive impact on the achievement of students and also on the quality of education. This study reveals that there was a strong relationship between the self-esteem and confidence level of students. It was observed that students with high self-esteem had a high level of confidence, especially in single-gender education system. At the same time, students' self-esteem and confidence level have bit impact on their academic achievement. The Achievement only depends on their intelligence and level of interest in studies, while the results were contradictory in researchers conducted by Wiggins and Schatz (1994), Scott and Murray (1996) and Saed (1999) found significant link in social skills, self-esteem and students' academic achievement. 
Besides this, a study revealed no statistically significant difference in the girl's self-esteem and academic achievement in the single sex and those in co-education. Although, the highest mean in self-esteem was in support of girls in SS and the higher mean of academic achievement was for girls in the co-education. This result was similar with the study done by Helat (2007) and opposed a study by Marlene Hamilton in Jamaica which showed that, females from single-sex schools perform the best academically, followed by males from single gender schools, boys from coeducational schools, and, lastly, girls from coeducational schools. In the classroom, when females participate actively and feel confident to answer any question, their confidence level increases. A big reason for the shyness in co-education class is the complex dependency of one gender on another. In this way, they express their feelings to one another, resulting in the high level of self-esteem. Certainly, the girls' students who took part in the study were in the same developing age, having the same concepts of the marriage, career capabilities, and new family structure that can distract their attention from forming an individuality and successful academic growth.

\section{REFERENCES}

Ahmad, N. (1984). Evaluation Process in Education System. AIOU, Islamabad, Pakistan. P. 6572.

Cherney, I. D., \& Campbell, K. L. (2011). A league of their own: Do single-sex schools increase girls' participation in the physical sciences? Sex Roles. 65 (9-10), 712-724.

Dale, R. R. (1974). Mixed or Single-Sex School? London: Routledge.

Datnow, A. \& Hubbard, L. (Eds.) (2002). Gender in policy and practice: Perspectives on singlesex and co-educational schooling. London: Routledge Falmer.

Department of Education (DoE). (2008). Northern Areas, Pakistan. Northern Areas Education Strategy, 2008-25.

Fullan, M. (2007). The New Meaning of Educational Change (3rded.). Teachers College Press, Columbia University, N.Y.

Goldstein, H., (1987). Multilevel Models in Educational and Social Research, New York: Oxford University Press.

Harker, R. (2000). Achievement, Gender and the Single-sex/coed debate. British Journal of the Sociology of Education, 21, 203-218.

Harter, S., (2018). Manual for the Self Perception Profile for Adolescents. University of Denver, Denver, CO.

Hashmi, N., Zafar, M. I., \& Ahmad, M. (2008). Cultural Determinants of Female Educational Attainment in Rural Jhang, Punjab, Pakistan. Pakistan Journal of Agricultural Sciences, 45, No.1.

Hawley, R. (2014). The Case for Boys' School. In. D.K. Hollinger \& R. Adamson (Eds.). Singlesex schooling: Proponents speak (11-14). Washington: US Department of Education.

Helat M., (2007). The effect of co-education on self-esteem of Jordan university and princess Alia university colleges students. Journal of Educational and Psychological Sciences, 8(1).

Hudley, C. (1995). Assessing the impact of separate schooling for African American male adolescents. Journal of Early Adolescence, 15, 38-57.

Jackson, C. K. (2012). Single-sex schools, student achievement, and course selection: Evidence from rule-based student assignments in Trinidad and Tobago. Journal of Public Economics. 96 (1), pp. 173-187. 
Khalil, B., Hashish, M., \& Dawood, L. (2011). Subject choice and occupational aspirations among pupils at girls ${ }^{e e}$ schools. Pedagogy, Culture and Society, 11, 425-442.

Lavigueur, J. (1980). Coeducation and the tradition of separate needs. In Spender, D., \& Sarah, E. (eds.), learning to lose - sexism and education (pp. 180-190). London: the women's press.

Lee, V. E., \& Lockheed, H. M. (1990). Sustained effects of the single-sex secondary school experience on attitudes, behaviors, and values in college. Journal of Educational Psychology, 82(3), 578-592.

Lee, V. E., \& Marks, H. M. (1990). Sustained effects of the single-sex secondary school experience on attitudes, behaviors, and values in college. Journal of Educational Psychology, 82(3), 578-592.

Lee, V.E. \& Bryk, A.S. (1986). Effects of single-sex secondary schools on student achievement and attitudes. Journal of Educational Psychology, 78, 381-395.

Mael, F. A (1998) Single-sex and coeducational schoolings: Relationships to socio-emotional and academic development. Review of Educational Research. 68:2, 101-129.

Marsh, H. W. (1989). Effects of attending single-sex and co-educational high schools on achievement, attitudes, behaviors and sex differences. Journal of Educational Psychology, $81,70-85$.

Marsh, H. W., Owens, L., Myers, M. R., \& Smith, I. D. (1989). The transition from single-sex to co-educational high schools: Teacher perceptions, academic achievement. American Science, $7(12)$.

Marsh, H.W. (1991). Public, Catholic single-sex and Catholic coeducation high schools: Effect on achievement, affect and behaviors. American Journal of Education, 99, 320-356.

Ministry of Education. (1998). Report on Commission on National Education, Islamabad, and Government of Pakistan, Pp.25-28.

Murphy, P., \& Ivinson, G. (2000). Construction of knowledge, social identities and pedagogy in single and mixed sex groupings. Paper presented at the Annual Meeting of the American Educational Research Association, New Orleans.

Nagengast, B., Marsh, H. W., \& Hau, K. T. (2013). Effects of single-sex schooling in the final years of high school: A comparison of analysis of covariance and propensity score matching. Sex Roles, 69 (7-8), 404-422.

National Association for Single Sex Public Education (NASSPE) (2006). Single-sex vs. Co-ed: The evidence. Retrieved fromwww.singlesexschools.org/evidence.html.

National Association for Single Sex Public Education (NASSPE). (2005). Single-sex vs. Co-ed: The evidence. Retrieved fromwww.singlesexschools.org/evidence.html.

Ogden, C. E. (2011). A Comparison of Student Performance in Single-Sex Education and Coeducational Settings in Urban Middle Schools.

Park, H., Behrman, J. R., \& Choi, J. (2013): Causal effects of single-sex schools on college entrance exams and college attendance: Random assignment in Seoul high schools. Demography, 50 (2), 447-469.

Pirzado, P. (2006). Exclusion of girls from education in rural Pakistan. EENET Asia Newsletter (2), 24-25 Available at: http://ecommons.aku.edu/pakistan ied pdck/21.

Redenbach, S., (2014). Self-Esteem, the Necessary Ingredient for Success. Esteem Seminar Programs and Publications, USA.

Reisman, D. (2017). A margin of difference: The case for single-sex education. In Blau, J. R. (Ed.), Social roles and social institutions, 241-257. Boulder: Westview Press. 
Riordan, C. (1994). Single-gender schools: outcomes for African and Hispanic Americans. Research in Sociology of Education and Socialization, 10, 177-205.

Riordan, C. (2014). Girls and boys in school: Together or separate? New York: Teachers College Press.

Robinson, P., \& Simthers, A. (1990). Should the sex be separated for secondary education comparisons of single-sex and coeducational schools. Research Papers in Education: Policy and Practice, 14(1), 23-49.

Rosenberg, M. (1965). Society and Adolescent Self-Image. New Jersey: Princeton University Press.

Rubie, C. M., Townsend, M. R., \& Moore, D. W. (2000). Motivational and academic effects of cultural experiences for the indigenous minority students in New Zealand. Educational Psychology, 24: 143-160.

Ruessel, S. (2007). MonoedukativeSchulen.Abrufbarunter:http://www.erziehungstrends.net LMonoedukation.

Saad, A. I. (1999). Self-esteem among Arab adolescents in Israel. Journal of Social Psychology, 139(4):479-493

Salomone, C. (2006). Different, Equal: Rethinking Single-Sex Schooling. New Haven: Yale University Press.

Scott, C. G., \& Murray, G. C. (1996). Student self-esteem and school system perceptions and implications. Journal of Educational Research, 96:286-298.

Wiggins. J, D., \& Schatz, E.L. (1994). The relationship of self-esteem to grades, achievement scores, and other factors critical to score counselor. Diss. Abstracts, 41(4):239

Yates, S.M. (2004). Aspirations, progress and perceptions of boys from a single-sex school following the changeover to co-education. International Education Journal, 4, 167-176.

Zafar, F. (2004). Gender Review of Education. UNICEF, Lahore, Pakistan. 